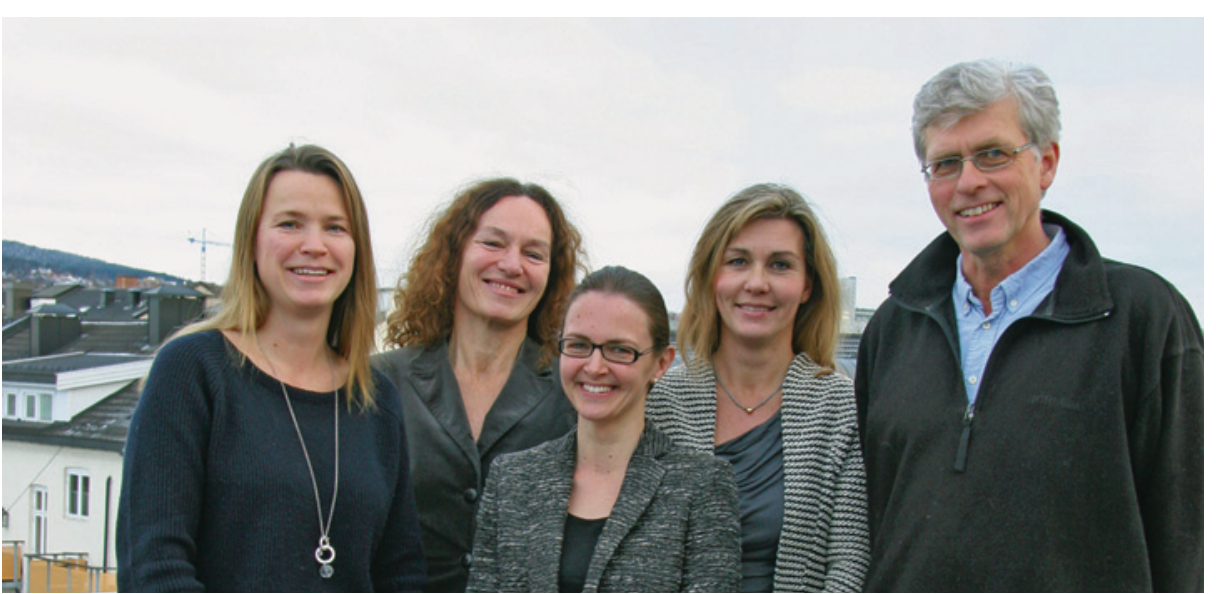

Fem av forfatterne: fra venstre Siri Eldevik Håberg (førsteforfatter), Camilla Stoltenberg (sisteforfatter), Nina Gunnes, Lill Trogstad og Per Magnus. Foto Torunn Gjerustad, Folkehelseinstituttet

\title{
Flere dødfødsler etter influensa, men ikke etter vaksine
}

\author{
Dødfødsler var vanligere for kvinner som var gravide under influensa- \\ pandemien i 2009 enn for dem som var gravide før eller etter pandemien. \\ Det viser en norsk studie.
}

Norske forskere ønsket å finne ut om pandemisk influensa og influensavaksinasjon under graviditeten påvirker risikoen for dødfødsel (1). Opplysninger om svangerskap ble hentet fra Medisinsk fødselsregister og vaksineregisteret, influensadiagnoser fra helserefusjonssystemet.

Hos kvinner som fikk influensadiagnose hos lege under influensapandemien i 2009, var risikoen for dødfødsel nesten dobbelt så høy som hos kvinner som fikk en slik diagnose før eller etter pandemien (justert hasardratio 1,91; $95 \% \mathrm{KI}$ 1,07-3,41). Det var ingen økt risiko for dødfødsel etter vaksinasjon, og vaksinering i svangerskapet reduserte risikoen for å få influensa (justert hasardratio 0,30; $95 \% \mathrm{KI} 0,25-0,34)$.

- Denne studien tyder på at influensavaksinering i svangerskapets 2 . og 3 . trimester ikke er forbundet med økt risiko for dødfødsel, men at influensasykdom i svangerskapet øker denne risikoen, sier førsteforfatter Siri Eldevik Håberg. - En dødfødsel er en sjelden hendelse, og man vet fra andre studier at gravide har økt risiko for å bli alvorlig syke av influensa. Derfor er det viktig at gravide vaksinerer seg mot influensa for å unngå alvorlig sykdom. I denne studien fant vi ingen uheldige konsekvenser for barnet av influensavaksinering, sier hun.

- Resultatene støtter anbefalingene om at gravide bør ta influensavaksine i $2.0 g$ 3. trimester. Vaksinering i svangerskapet blir gitt for å beskytte gravide mot alvorlig influensasykdom, men beskytter også barnet mot influensa like etter fødselen.
I Norge har vi en unik mulighet til å studere konsekvenser av vaksinasjon og influensa på grunn av vårt vaksinasjonsregister og fordi influensavaksine ble tilbudt hele befolkningen i forbindelse med pandemien i 2009. Bred vaksinasjonsdekning kombinert med gode helseregistre gjør at vi har et godt datagrunnlag for slike studier, sier Eldevik Håberg.

\section{Norsk vaksineforskning}

Studien ble initiert av Folkehelseinstituttet da de første rapportene om aborter og dødfødsler etter pandemivaksinasjon kom. Forskere ved Folkehelseinstituttet i Oslo og Bergen samarbeidet med forskere ved Legemiddelverket og National Institutes of Environmental Health Sciences (NIEHS) i USA. Studien er finansiert av Folkehelseinstituttet.

Forfatterne av artikkelen er Siri E. Håberg, Lill Trogstad, Nina Gunnes, Allen J. Wilcox, Håkon K. Gjessing, Sven Ove Samuelsen, Anders Skrondal, Inger Cappelen, Anders Engeland, Preben Aavitsland, Steinar Madsen, Ingebjørg Buajordet, Kari Furu, Per Nafstad, Stein Emil Vollset, Berit Feiring, Hanne Nøkleby, Per Magnus og Camilla Stoltenberg.

\section{Erlend Hem}

erlend.hem@medisin.uio.no

Tidsskriftet

Litteratur
1. Håberg SE, Trogstad L, Gunnes N et al. Risk of fetal death after pandemic influenza virus infection or vaccination. N Engl J Med 2013; 368: 333-40.
Ordforklaringer

Dødfødsel: I denne studien var dette definert som alle dødfødsler etter svangerskapsuke 12 som er registrert i Medisinsk fødselsregister.

Pandemiperioden: I denne studien var denne definert som tiden fra og med 1.10. 2009 til og med 31.12. 2009.

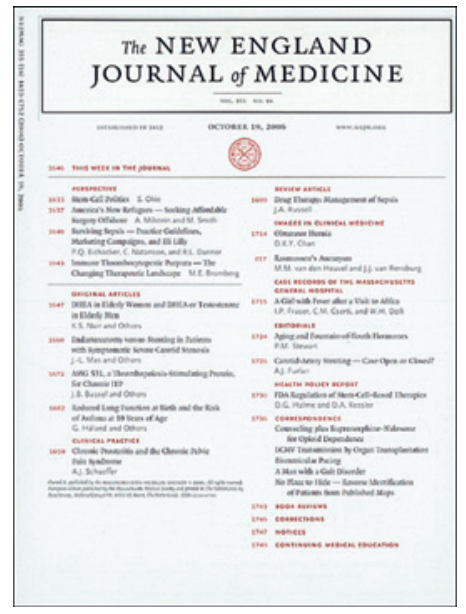

Artikkelen ble e-publisert 16.1. 2013 i New England Journal of Medicine (www.nejm.org), som er verdens høyest rangerte generelle medisinske tidsskrift. (c) New England Journal of Medicine 